\title{
The Inculcation of Critical Reflection through Reflective Learning Log: An Action Research in Entrepreneurship Module
}

\author{
Yeoh Khar Kheng ${ }^{1}$ \\ ${ }^{1}$ School of Business Management, Universiti Utara Malaysia, Malaysia \\ Correspondence: Yeoh Khar Kheng, School of Business Management, Universiti Utara Malaysia, Malaysia. \\ E-mail: kharkheng@uum.edu.my
}

Received: July 22, 2017

doi:10.5539/ies.v10n12p153
Accepted: August 31, $2017 \quad$ Online Published: November 28, 2017

URL: https://doi.org/10.5539/ies.v10n12p153

\begin{abstract}
Purpose-This study is part of the Scholarship of Teaching and Learning (SoTL) grant to examine written reflective learning log among the students studying BPME 3073 Entrepreneurship in UUM.

Method-The data collection techniques is researcher-directed textual data through reflective learning log; obtained from students of one hundred forty. A qualitative thematic method was employed to examine the verbatim format of students' reflections.

Findings-The empirical results found out majority of students have little academic experience in writing a piece of reflective textual learning log. Resultant in their incapability's to reflect critically and thus; unable to translate their thinking in the written format. Data collected from three classes of Entrepreneurship registered fifty five percent $(75 \mathrm{logs}$ ) of learning $\log$ as Level 1 (descriptive writing); therefore they were not suitable for further analysis. The remaining 61 reflective learning logs were used for the textual data examination. The students' reflections on their Entrepreneurship's experience can be categorize systematically into four different themes comprised of (1) The nature of Entrepreneurship module, (2) Entrepreneurial characteristics, (3) Opportunity recognition, and (4) Creativity \& innovation.

Significance-The results of this research have strongly suggested the need to urgently develop among the students the skills in writing reflectively as they go through the process of higher education which is useful in molding their future professional and entrepreneurial behavior as when they entered the job market which requires a critical reasoning ability.
\end{abstract}

Keywords: critical thinking, critical reflection, action research, reflective learning log, entrepreneurship, thematic analysis

\section{Introduction}

In the academic realm, entrepreneurship by definition, is being characterized as the uncanny ability of an individual to spot opportunity, to obtain and leverage on scarce resources, strategies and implement the plans to produce products/services in exchange of profits. They innately know how to manipulate all the possessed and non-possess resources to their advantage. The description seems to suggest the act of entrepreneur as a linear process, but, the above definition differs in stark contrast to the practice of entrepreneurship. In actuality, the entrepreneurship process is dynamic and chaotic. Thus, Greene (2014) devised four methods to impart entrepreneurship knowledge. They are (1) Do small business, (2) Serious gamification and business simulations, (3) Learning through design thinking, and (4) Reflections. All these four complementary techniques are based on the premise that the module of Entrepreneurship should be taught as a method.

Each method requires learners to extend beyond the process-based paradigm of knowing; analyzing, and talking, instead positioning the learners to create, apply, and act (Greene, 2014). In this SoTL study, the researcher adopts the reflective practice as a method for teaching entrepreneurship and the toolkit used is the reflective learning log. Given its importance, reflective skills have now been recognized as an important proficiency among the professionals and being treated as a good source for critical thinking development, enhancing self-monitoring as well as leading to one having developed good reasoning skills. Furthermore, reflective exercise has also become a vital component of most professional degree programs, namely nursing, teaching as well as many business capstone courses that require final year students to recap and reflect before the end of their university's tenure 
(Chalk \& Hardbattle, 2007).

Reflection is a significant process by which knowledge is derived from experience. When reflecting, one considers an experience that has happened and tries to understand or explain it, which often leads to insight and deep learning - or ideas to test on new experiences. Reflection is particularly important for puzzling experiences, operating under conditions of high ambiguity, and problem-solving. As a result, it should not be a surprise that reflection is a pivotal component of entrepreneurship education and also a way of practicing entrepreneurship.

In this study, the researcher hopes the students in BPME 3073 Entrepreneurship to develop a strong sense of awareness and appreciation of reflecting by looking at what they are doing/learning now in Entrepreneurship module. This type of reflection is often referred to as "reflection-in-action" (Schon, 1987). Students who lack of this reflection-in-action are likely to make mistakes of repeating the same dysfunctional behavior/attitude/decision in their future career/entrepreneurial endeavor, therefore impede their advancement in their respective fields. Students who possess this appreciation of reflection demonstrate it through reflective writing. Reflective writing is a metacognitive, "thinking about your thinking" process (Martinez, 2006). As a metacognitive process, the student is able to appreciate the deeper, underlying issues (Martinez, 2006), rather than accepting a superficial interpretation of the problem, which may present in a professional/entrepreneurial context (Mair, 2011).

This unit of analysis of this research was the third and final year students of entrepreneur and BBA in University Utara Malaysia. As to evaluate the appreciation of reflection-in-action among my students of Entrepreneurship, they have to submit (Week 10) one reflective learning logs for the purpose of formative assessment.

Yinger and Clark (1981) believe that written reflection is more useful and meaningful than oral reflection. The verbatim format of a reflective log has been hailed as new to my students given that the routine formative coursework's of this module usually comprised of quizzes, tests, guided business plan and summative exam.

This research was carried out with the 3 main aims as to:

1) Analyze the extent to which students who are taking entrepreneurship module can reflect critically on the learning process,

2) Categories the emerging themes of entrepreneurship from those who fulfill the Hatton \& Smith's level of critical reflection $(2,3 \& 4)$ and,

3) Examine the insight from those who can reflect critically in their learning log.

\section{Significance of the Study}

In this SoTL study, the researcher adopts the reflective practice as a method for teaching entrepreneurship and the data collection techniques is researcher-directed textual data through reflective learning log. Given its importance, reflective skills have now been recognized as an important proficiency among the professionals and being treated as a good source for critical thinking development, enhancing self-monitoring as well as leading to one having developed good reasoning skills. Furthermore, reflective exercise has also become a vital component of most professional degree programs, namely nursing, teaching as well as many business capstone courses that require final year students to recap and reflect before the end of their university's tenure (Chalk \& Hardbattle, 2007). However, actually putting vague thoughts or feelings into a format that other people read is not a process that some people enjoy or find easy (Harvey \& Knight, 1996) and such skills can be especially difficult to develop for Malaysia's students which traditionally have adopted Instructivist learning techniques.

\section{Critical Reflective Learning}

It is difficult to compose our reasoning process in a type of reflection yet it ought to be practiced in learning, it typifies learning in a considerably more significant way. The utilization of reflective learning log can help to report thinking process which in turns encourages educator to reach a conclusion on the learning advancement of the students. The whole process of composing in such manner may have some way or another forced student to ponder on what they have been learning in class and in this manner to encourage further learning. According to Cowan (1998, p. 16), a student is said to be doing reflection when..."he notices that there is something peculiar about the issue that she is pondering, in comparison with the cases she has experienced in class; and when she also contrast what the difference is, and what she ought to do about it."

Dewey (1933) opined that reflection enables one to be taking part in profound thought with a specific aims to get an intricate importance of something, changing over instability into understanding which prompts activity. This is in agreement to what Moon (1999) in which reflection involve mental action that happens in connection to the handling of complex thoughts which are ordinarily found during the process of learning. In this way, in order to 
understand the advantages of reflection, students ought to be required to reflect and to compose a reflective log with the goal that they can see the significance of the learning exercises that have been done. Accordingly, reflection log will uncover the reasoning since the whole procedure of composing is indeed cognitive activity (Luidens, 1997). Besides, idea illuminations and alterations happen because of the need to introduce information in various formats amid the reflection writing process. In that capacity, it is normal that amid this process, the student will have the capacity to evolve new perspectives and view the information in a different angle (Yinger $\&$ Clark, 1981).

\section{Methodology}

The research methodology used in this study was classroom-based educational action research (Angelo, 1991; Elliott, 1991). Part of effective teaching is the ability to reflect on what is happening in the classroom, and to identify any differences in what was planned and what actually occurred. By conducting "systematic, intentional inquiry" within his/her own classroom, the instructor builds a better understanding of his/her own practice (Cochran-Smith \& Lytle, 1993, p. 7).

Toward the start of the academic session of 2015/2016, all students registering the BPME 3073 Entrepreneurship in University Utara Malaysia had been made aware of the idea of reflective writing through the reflective learning $\log$ (Moon, 1999) that will be graded as part of their coursework. The motive to include the reflective learning $\log$ as a major graded coursework is to entice students to take a serious attitude due to the syndrome of "strategic learner" (Kneale, 1997) meaning which, any class activities which is not graded may not able to secure participation and attention from the students. Besides, not to include the reflective learning log in a formal appraisal can send a negative message to the students about the importance of this piece of reflective assignment. Towards the end of the semester, it was found that four students did not submit their reflective learning log. Hence, only 136 learning logs were obtained to examine the themes and the level of the critical reflection.

In this qualitative research, one hundred forty students of three classes (as a unit of analysis); in which they have to submit one graded reflective learning logs that will go towards the final mark of ten percentage. At the very beginning of the class, students have been informed that they might only be compensated a maximum of five percent should they descriptively compose the reflective learning. Thus, the researcher will considers those students who could acquire a score of over 5 percentage points, can be considered as the individuals who could accomplish the learning outcome of the formative assessment (refer to Appendix 2).

Integrity guidelines were strictly observed in this study. All the students' agreement to participate as respondents had been obtained and I use pseudonyms to report the results in this study was strictly adhered to. This is to make sure my students have no whatsoever hesitation in expressing their opinions, thoughts, doubts, and any inhibiting elements that will not make them reflect critically (Marshall \& Rossman, 1999). This academic freedom is paramount to groom student to become critical thinkers.

\subsection{The Framework for Critical Reflection}

Since this reflective learning log is a graded formative assessment, all the students had been briefed on reflective learning log, in terms of their formats, the benefits, the different writing techniques, types of reflection and levels of reflection. For the purpose of the evaluation, the researcher adopted the framework as recommended by Hatton and Smith (1995) with the aims of awarding marks and increasing objectivity. The framework contained four levels of reflections (Hatton \& Smith, 1995) (which was made know to the students as marking rubric) as delineated underneath:

(1) Descriptive reflecting work (contains no elements of reflection)-Level 1

(2) Descriptive reflection (a portrayal of occasions with reflection from one point of view) -Level 2

(3) Dialogic reflection (some "stepping back" from occasions and the acknowledgment of optional perspectives) - Level 3

(4) Critical reflection (mindfulness that similar activities and occasions are seen contrastingly by various people) - Level 4

In carrying out the study, the researcher gave a verbal assurance to the students that their marks will not be deducted when they give truthful and critical account on any topics reflected in this Entrepreneurship. In a similar light, the students were likewise being reminded that their evaluations won't be influenced emphatically should it contain simply compliments for the said module. The students were informed that assessment will exclusively fixate on the nature of reflection indicated in view of the Hatton and Smith's (1995) framework.

A very simple hand guiding framework were given to student in undertaking their reflective learning log by 
providing three cues which they could structure their reflective log around. The first question was: What have you learnt from the module up until this point? The second was what are the main points in this module that give you knowledge on turning you into an entrepreneur? The third question was in what capacity will you have the ability to utilize the learning from this module in your professional career?

The prompts were used to lead the students to compose a piece of critical, reflective learning log and prevent them from deviate too far from the objectives of this academic exercise. But, only twelve students used the scaffolding structure, most of them written the learning log through a free-form style. The reasons why only handful students utilize the three cues to write simply point to the fact that it was much easier to write descriptively than critically. To reflect critically and to write the reflection in a critical manner is very demanding. Hence, writing reflective learning logs should be encouraged further because it is very educational by nature to our students.

\section{Analyses and Discussions}

Based on the score sheets for reflective learning logs (see Appendix 2), the Table 1 presents the percentage of scores for the graded reflective learning logs.

Table 1. Frequency of score percentage for graded reflective learning $\log \&$ the achieved level of reflections

\begin{tabular}{cc}
\hline Percentage of Score & Frequency \\
\hline $1 \%-5 \%$ & 75 (Level 1) \\
$6 \%$ & 35 (Level 2) \\
$7 \%$ & 17 (Level 3) \\
$8 \%$ & 7 (Level 4) \\
$9 \%$ & 2 (Level 4) \\
$10 \%$ & 0 \\
\hline
\end{tabular}

All of the reflective learning logs in the findings were obtained from the students that have achieved the score of six percentage points to nine percentage points based on Appendix 2. Seventy five (approximately fifty five percent) of the reflective learning logs was categorized as level 1 (from one percent to five percent) in which the reflections were merely descriptive in nature. As a result, they were not included in the analysis. The remaining of sixty one reflective learning logs was considered to be above Level 2 achievement of reflection and this study used all of them for further analysis. Considering seventy five learning logs had been disposed of were large (approximately fifty five per cent), it may give a noteworthy indication that to reflect and to write critically can be trying. This is due to the absence of capacity in thinking critically or it could likewise be an indication that the students were basically not inspired in doing this formative assessment at all.

To examine and to categories the findings from these reflective learning logs, the approach of thematic was used in this study. All sixty one reflective learning logs were used in anonymity and all reflections were in written format. In examining the textual data, the researcher used open coding (based on constant comparative methods) (Strauss \& Corbin, 1998) to highlight reflection themes that keep repeatedly developing across the writing exercise from my students in Entrepreneurship module. The researcher assigned labels to the reflective learning logs, as a means to identify patterns in the students' reflection and discussion. In addition, the researcher also engaged in peer examination to ensure that the textual analysis was reliable and that the researcher owns biases and predispositions would not affect the interpretation of the data (Gray, 2004).

The students' reflections on their Entrepreneurship's experience could be grouped into four different reflection organizing themes comprised of:

1) The nature of Entrepreneurship module,

2) Entrepreneurial characteristics,

3) Opportunity recognition, and

4) Creativity and innovation.

\subsection{Entrepreneurship Module}

This theme was formed based on the student's reflections on the essence of the Entrepreneurship module. At the beginning chapter, much has been written on the Entrepreneurships as an academic discipline and it was a heated debate. Students in BPME 3073 were being informed on this academic debate. Forty five reflective samples were written related to the debate of Entrepreneurship as an academic discipline. Some thirty students reflected 
in the Entrepreneurship module as exciting and eye opening. But six students strongly opined the module is too general, too obvious and plain common sense. BPME 3073 did not specifically teach them the intricacies of being a real entrepreneur, but just to pass their examination. Some people say - entrepreneurship cannot be taught in the classroom setting. Below were the excerpts from our students whose names had been disguised:

Sonia: After study this module for more than 6 weeks, I found that this module of entrepreneurship is unnecessary and should not include in the BBA syllabus. This is due to the fact that entrepreneur is a person who hated study and hated going to school so much and they quit school. They are lazy come to study books. That is the reason they become entrepreneur. Nobody wants them. They are on their own. My good friend told me that, in present day, even if you have degree, but the pay still very low and not enough to fulfill all the monthly expenses. Thus, my friend made the decisions to quit university and venture out to seek her own future. I can't comprehend my friend decision to stop university [sic].

Sonia was questioning the legitimacy of this module as she found this module was not useful for her. From her anecdotal example presented above, she opined that to be an entrepreneur, she does not need to study Entrepreneurship as a subject because many successful entrepreneurs never set foot in the ivory tower, they just do it (she quotes the budding entrepreneur dislike study). She even goes to the great length to argue that a degree was not sufficient to guarantee a successful life thereafter.

May: In my humble view, this "Entrepreneurship" subject was irrelevant to study. My past experiences on this kind of subject were dulled and I register it just to fulfill my BBA credit requirements. I think we do not need to register for BPME 3073 at all. For me, to become a real entrepreneur, do not need to memories all the entrepreneurship theories. Because even we have study by hard all the entrepreneurial theories, it cannot transform us to become budding entrepreneur. As for the true entrepreneurs, they become a successful entrepreneur even though never take this subject. This module cannot turn me into one entrepreneur, may be can for some of my classmates! But when study this module, I dream to become a respectable entrepreneur like Tony Fernandez [sic].

As like Sonia, May, also poured her heart out on this subject in the negative way (irrelevant to study). May wants to be a successful entrepreneur, but she did not think studying the module per se with all the Entrepreneurship's concepts and theories will transform her to become one (it is still not guarantee us to become a successful entrepreneur). Similar to Sonia, May also questioned the legitimacy of this module as they felt bored, wasting their time and to the very core, they just to complete their credit hours of this module to obtain a degree.

But what expressed above by Sonia and May did not reflect the current trend in the world of business and academic. In recent years, we have seen an extraordinary proliferation of entrepreneurship and small business courses and programs in colleges and universities worldwide (Solomon, 2006). From its origins until today, entrepreneurship research and teaching has met many important milestones. It appears that such rocketing interest in entrepreneurship has shaped not only scholarly writing, but also initiated a "revolution" in entrepreneurship education at academic institutions. This "revolution" has also sparked an interesting scholarly discourse between Kuratko $(2004,2005)$ and Katz $(2006,2008)$ about the maturity and legitimacy of entrepreneurship as not only a field of study but also a field relevant to higher education.

In other words, the adoption of programs (i.e. entrepreneurship) makes the higher education institutions like UUM relevant and it signals that UUM graduates have the preparation they need to succeed in a competitive environment. This goes as far as hiring employees based on the legitimacy they provide to the institution (UUM) rather than their (graduates) actual capabilities. This should augur well for UUM graduates like Sonia and May as it was compulsory for all BBA undergraduates to take this module.

As with Entrepreneurship's theories as highlighted by May, Fiet (2001) specifically addresses this issue when he observes the large number of adjuncts that teach entrepreneurship:

Students must learn theory in order to understand the future consequences of their entrepreneurial decisions. Thus, it seems improbable that adjuncts can effectively teach the course. Teaching theory is rarely the strength of adjuncts (Fiet, 2001, pl. 9).

Edi: My initial view on this Entrepreneurship class is that it will be very interesting as it will train me to become an entrepreneur. It is cool. But at the same time have some worries as it might involve a lot of readings and readings is hard. True to my predictions, yes, it involved a lot of reading but it is fun as that I immersed myself in the topic that I read. For instance, business franchise is a "hot" topic in this module. Thus, it entices me to wonder far that in the future I will become a very rich franchisee and how will be exciting in managing the franchise. As a bumiputra, I intend to become budding successful entrepreneurs and I would aspire to become 
like them in the near future [sic].

Keat Meng: Based on the knowledge that I had learned in the class, I have a clearer understanding about what is entrepreneurship and it change many of my misconception about entrepreneurship. It really inspires me. However, becoming an entrepreneur is not an easy task because they have to face many problems and make the best choice of every decision. It needs a good planning before we start our business [sic].

Despite the negative attitude in this Entrepreneurship module, positive changes in Edi's behavior reflected through his comments as well as the realization from Keat Meng can be quite motivating as both of them start to aware the beneficial aspects of this module. A cursory review of most of the reflective learning logs displayed the similar viewpoints as echoed by Edi. Many topics in this module had managed to correct their long held misassumption and misperceptions on their worldview on entrepreneurship. They start to appreciate that $21^{\text {st }}$ century business globalization indeed needs entrepreneur to go through a systematic training as like this module to cope with the onslaught of the globalization. This module also stimulates Edi's imagination as he envisions himself as a successful franchise entrepreneur in the future. He went on to search list of successful bumiputra entrepreneurs so that Edi can emulate and be good as them. As for Keat Meng, he managed to correct its misinterpretations on the concepts of entrepreneur and aspire to become one. He also has high awareness that to start a business is no easy feat can be done with good planning (It needs a good planning before we start our business).

\subsection{Entrepreneurial Characteristics}

Sixty one reflective learning logs were related to the entrepreneur's traits and idiosyncrasies. Thirty five students made specific reflections that learning the entrepreneurial characteristics had demonstrated the importance of "taking calculated risks, ideation, control of our own future", something they had not done previously or that the "module has made me rethink my personal beliefs and has made me consider to become entrepreneur". Many students made specific reflections about their intention to use whatever they had learnt from the module to help them venture into their small businesses and achieve their "dream". In short, this module reveals the secret ingredients that mold successful entrepreneur like Tony Fernandez "invincible"

Zaitun: I discovered that even woman have a major potential to become successful entrepreneur. Not only man can become successful entrepreneur. The video shown in the class demonstrates that woman likewise have the business attributes that the men had. The woman likewise has the strong enthusiasm, discipline and desire to become successful entrepreneur and this passion is as much as men. As I would like to think, everybody likewise can turn into a successful entrepreneur regardless of the gender, age, and nationality. It is just relies upon the individual themselves that they truly need to be [sic].

Zaitun reflects emotionally for the above account. As a woman, Zaitun strongly opined that a successful entrepreneur does not belong to man only; woman as shown in the video during the class can also become successful. In her frame of mind, woman equal with man in the endeavor of entrepreneurship. Clearly, in this account, self-questioning is evident (an 'internal dialogue' is set up at times) in Zaitun and she is deliberating between different views of her own mindset on woman entrepreneur (before and after watching the video on Ugandan women entrepreneurs making straw bags). This account shows quite deep reflection, and it does incorporate a recognition that the frame of reference with which an event is viewed can change according to the emotional state in which it is written, the acquisition of new information (through the video), the review of ideas and the effect of time passing.

Lina: In any case, the most intriguing thing in Chapterl is that it makes me think more whether I ought to be an entrepreneur or not, and if I need to be entrepreneur why? As I thoroughly consider all once more, I imagine that being entrepreneur may be something to be thankful for me since I truly need to have my very own full control life, and offer something to my family particularly my folks, and lives like how I have dream some time recently. In any case, at that point when consider the difficulties to be entrepreneur these days, it sort of breaking me apart as I envision myself in an extremely challenging predicament of being entrepreneur. Simply considering the challenges that I will confronted makes me thinking about how extreme the life it is for those entrepreneur when they initially began [sic].

Like Zaitun, Lina is self-questioning herself (whether I should be an entrepreneur or not?). Lina is deliberating between different views of her own behavior (different views of her own and others). She delves into the question "Why I want to become entrepreneur"? She starts to envision the benefits of becoming one successful entrepreneur, but also worry about the huge challenges that are going to be encountering before becoming one. Lina says: "But then when think about the challenges to be an entrepreneur nowadays, it kind of breaking me apart as I picture myself in a very difficult situation". This shows Lina is learning new skills in contemplating 
and decision making. In addition, it unveils the feelings of insecurity when she visualizes the difficult road ahead of a budding entrepreneur.

Rosna: There are a few characteristics of an entrepreneur. Dare to take risk, hardworking, creative and innovative, open-minded, energetic, self-confident, and optimistic are some of the characteristics of the entrepreneur. Some of the people believe that entrepreneurs are born not create. However, it is not true. Most of the entrepreneurs are force to be an entrepreneur because of their condition. Sometimes, when people migrate to the other place, they will start a new business too because they have nothing at the new place. Beside, entrepreneur nowadays are born through knowledge. There are myths that say that "entrepreneur is those who do not do well in their academic." However, I do not agree with it [sic].

Rosna critically analyzed and opined that: "Some people believe that entrepreneurs are born not create. However, it is not true." She recognizes how prior experience, thoughts (own and other's) interact with the production of her own behavior. She gave her own opinion and explains critically that: "Most of the entrepreneurs are forced to be an entrepreneur because of their condition." She goes on to explain all the rationale of why the entrepreneur is not born, but due to their predicaments. She also cited that immigrants tend to become an entrepreneur in the host country because their lack of origin endowment. Again, self-questioning is evident in her reflection; deliberating between different views of her own behavior (different views of her own and others). She further says that: "entrepreneur, nowadays are born through knowledge" and use this statement to debunk the myths that says: "entrepreneur is those who do not do well in their academic."

Rosna succinctly supported her argument with: "entrepreneurship has become a core subject for every university's student", such as in Malaysia context, therefore, all Malaysian entrepreneurs are well educated in the future. This is a logical argument. There is clear evidence of dialogic reflection in the final writing of Rosna. Ironically, Rosna reflection on the last thought of well-educated entrepreneur, stand in total contrast with the reflection of Sonia, which says: "Entrepreneur is the person who dislikes study."

\subsection{Opportunity Recognition}

As with entrepreneurial characteristics, all $61 \operatorname{logs}$ contained reflections that related to the theme of opportunity recognition. The ability to recognize business opportunity is the main trait of any successful entrepreneur. According to the definition that researches consider the opportunity to be laying at the heart of the entrepreneurial process, an entrepreneur is an individual who is able to identify, evaluate and exploit opportunities (Shane, 2003; Venkataraman, 1997).

Faridah: How we describe opportunity? Consider the possibility that, when opportunity come, and we don't know anything about it. After the class I attempt to look on the web about the meaning of opportunity. At that point just I understand that, there's no any specific definition about. Suppose in one situation, there are less people selling fried banana at the territory, at that point a man begin a fried banana business without understanding these variables. Does it imply that the individual didn't perceive the opportunity and snatch it? In my understanding, I don't think the individual grab the opportunity despite the fact that he made an awesome job. To me, opportunity acknowledgment more towards the individual continue pondering what sort of food has not been offering at his area, at that point he make sense of that it's fried banana! [sic].

Reflection by Faridah depicts the student engaging in asking self-critical question about what is "opportunity". That made her thinks very hard about this magic word and then; synchronizes the meaning of "opportunity" to his/her own cognitive map.

Self-questioning is evident: "What if, when opportunities come, and we don't know anything about it?" This critical question posed by Faridah demonstrated there are sense of 'mulling about', discourse with self and an exploration of the role of self in entrepreneurship module. Faridah tries curiously to find the meaning of "opportunity". Even though Faridah cannot find one to her satisfaction, she did try to make sense of the term with a good example. The example given showed Faridah try hard to find closure on the term "opportunity"

Rahimah: I once worked at a general store that offers merchandise worth RM2. I discovered numerous purchasers buy products in our store on the grounds that the cost is less expensive than other stores. In uncertain financial conditions, high costs would make the clients to change to cheaper store that can offer low costs for them. This demonstrates the entrepreneur can utilize innovative pricing mechanism in difficult economic situation as an opportunity to offer their products.

In the above account, Rahimah try to connect her working experience in the supermarket and the entrepreneurial concepts of creative pricing, opportunity and economic conditions. Rahimah use her keen sense of observation to deduce the concepts of "opportunity" by making a connection between low price strategy and uncertain 
economic situation. Her reflection signifies opportunity never fall from the thin air, but rather through skillful orchestration between strategy and environment.

Wong: Opportunity is very important for an entrepreneur because opportunity is rather than just idea. If an entrepreneur has a good idea, but he or she do not has the chance to present or show to the other which mean that his or her idea will not be known by the public and hard to success. They always need to observe and understand the trend of the business. In addition, they will not miss the opportunity which will change the future of the business. Beside, entrepreneur must be sensitive to the surrounding. A little change of the environment may lead to a huge change of the business especially the technology. Therefore, every entrepreneur must put effort in finding the opportunity and sensitive to the surrounding to ensure that their business can be success.

Wong reflective writing is a metacognitive, "thinking about your thinking" process (Martinez, 2006) through "Opportunity is very important for an entrepreneur because opportunity is rather than just an idea. If an entrepreneur has a good idea, but he or she does not have the chance to present or show to the other which mean that his or her idea will not be known by the public and hard to success" and "A little change of the environment may lead to a huge change of the business especially the technology".

The above account requires Wong to use analytical skills (i.e. higher order thinking skills), to differentiate between idea and opportunity rather than merely create a narrative. As a metacognitive process, Wong is able to appreciate the deeper, underlying issues of entrepreneurship (Martinez, 2006), rather than accepting a superficial interpretation of the problem, which may present in an entrepreneurial context such as technological advancement (Mair, 2011).

\subsection{Creativity \& Innovation}

Forty five reflective learning logs comprised of the topic business creativity and innovation. Many reflections cite that there are vast differences between creativity and innovation. Shane (2003) emphasizes an entrepreneur's creative role in innovation, with the observation that many founding teams use various forms of brainstorming to increase the number of new ideas, and thus enhance creativity as an important foundation for innovation. For many aspiring entrepreneurs, creativity and innovation become the convergence of the reflections.

Wen Hui: Entrepreneur need to produce novel idea in business to deliver new product not yet available in the market and that can't be imitated by contenders. For instance, Cirque de Soleil, which utilizes 'Blue Ocean Strategy', in a business where no business visionaries who can compete in the business. Cirque de Soleil has been working together novel circus where it has artists who have high mastery and extraordinary in doing fascinating gymnastic activities. This circus business receives overwhelming reaction from customer since it is unique in relation to the ordinary circus [sic].

Wen Hui quote world class circus like Cirque du Soleil, which uses the Blue Ocean Strategy come to the fore of her reflection. She was able to connect creativity and innovation with Cirque du Soleil. The Blue Ocean Strategy requires the entrepreneur to create new ideas to produce new products not yet available in the market and cannot be imitated by the competitors. The uses of this unique example demonstrated the depth of propositional knowledge and the ability of Wen Hui to connect innovation and business bottom-line.

Juliana: Today our class instructor let us watch a video about lady entrepreneur in Uganda. From this video I can see it is an exceptionally poor nation. However, people did not surrender their life; they are doing diligent work for progress, particularly for woman entrepreneur. A woman entrepreneur gathers utilized straw from trash site, reuse the utilized straw and change item like into woman purse, shoes, and lady embellishments. From here I see the woman entrepreneur is exceptionally inventive. At the point when the machine used to straighten the straw breakdown, she even utilized her own particular teeth and blade to smooth the straw [sic].

Juliana is touched by the heart-wrenching video showcased true-grit creative women entrepreneurs in a poverty stricken country called Uganda. Through this video, Juliana narrates what she observed from the hard lives of the woman entrepreneur in Uganda. The description is succinct - just sufficient to raise the issues. Extraneous information is not added. It is not a story. The focus is in the attempt to reflect on the event and to learn from it. There is more of a sense of Juliana standing back from the event in the video; in order to reflect better on her actions and in order to be more effectively critical.

\subsection{Descriptive Writing (Non-Existence of Reflection)}

In this SoTL, there were seventy samples of reflective learning logs that scored five per cent and below five per cent point (see Appendix 2). All of them achieved Level 1 (non-existence of reflection) in the reflective framework proposed by Hatton \& Smith (1995). Descriptive writing is a depiction of events or academic reports. There is no critical discussion but a mere regurgitation of the event. Most of the reflective learning of this 
category is considered not to show any confirmation of reflection. The followings are some of the accounts:

Aminah: Franchising is a partial autonomous business that individual pays the franchise fees and royalty in exchange for the brand name and trademark that will be used to sell the high acclaimed product and their service. This business model is much easier to manage and less risk compared to the entrepreneur that set up their own business. For instance like Mc Donald which has establishment for everywhere throughout the entire that numerous franchisees pay the charges to maintain their business (sic).

This account written by Aminah is descriptive and it contains little reflection. The account describes what is a franchise, its characteristics and some of the benefits - but all in the context of an account of the event. Generally, one point is made at a time and ideas are not linked. It was wordy, tended to be meaningless and lacked sophisticated vocabulary. Overall, the writing was particularly colloquial in style.

Ana: A business person is somebody who arranges, oversees, and accepts the risk of a business or venture. A business person is a catalyst of progress. Additionally, a business person who is makes profits. The profits and loss arrangement of free enterprise serves to rapidly deal with the numerous new configurations of resources find [sic].

The above definition written by Ana was well versed but the entrepreneurial concepts are taken on without questioning them or considering them in depth. It is very descriptive. It could be a reasonably written account of an event that could serve as a basis on which reflection might start on an entrepreneur's risk taking behavior and efficient resource allocation through the profit-and-loss system, though it hardly signals any material for reflection - other than the last few words stated "positive side of business failure".

Fais: Lecturer start new chapter on the topic of capitalizing and financing. In this part lecturer clarifies why most new start up require financing or subsidizing. What's more there is additionally help to discover alternative asset monetization, for example, venture capitalist, crowd financing and inventive sources. Lecturer are additionally clarifies about bootstrapping, meaning which being thrifty and there are nine variations of bootstrapping strategies [sic].

Instead of using first party address, Fais tends to use third party address such as lecturer in writing his reflection. Critical reflection very much focused on the individual discourse with self and an exploration of the role of self in events and actions. The above narration is very much descriptive in nature and hardly contains any significant materials for reflection. The writing reflects a mere regurgitation of learning materials from the textbooks and the lecturer's power point slides. There was a lack of sophistication in the writing.

The reflection by the above three sampled students in this study indicated the reflective learning logs were descriptive in nature. The writings from the reflection, learning log were a mere regurgitation from the PowerPoint slides and text books given in lectures throughout the 14 week class. They were written in reporting style, all in regard to the account of the event and enlisting everything happen in that particular week. The reflective learning log failed to capture subjective elements like thoughts, feelings, how well (or bad) it went, what the students had learnt, what he/she will do differently next time (Miller, Tomlinson, \& Jones, 1994). Based on the frequency of score for graded reflective learning log, seventy five students merely self-reported the contents of the lectures throughout the semester that have no reflection at all (some of their reflections were highlighted in the reflections of student 16-20). Another thirty five students produce the works that contain descriptive reflection from one perspective. Only twenty six students were able to reflect critically at level four (Hatton \& Smith, 1995) in certain themes in entrepreneurship module.

\section{Conclusion}

This SoTL found out that reflective writing was a new kind of assessment to many business students and should have been unequivocally instructed in the respective subject. The results have affirmed that a pressing need for the adoption of critical writing skills among the undergraduate students so to help them grow professionally and develop their entrepreneur aptitude. The ten percent weighting given to this graded formative assessment and it is a substantial grade. While the result of the study may not offer solid evidence on the capability of the students in reflective writing, it will be abnormal, should inability exist due to the attitude problems of willingly to forfeit ten percent by not writing reflectively. Thus, it may necessitate further examination.

In view of the findings of the sixty one understudies who had shown a capacity in reflective writing, it is proposed that maybe the university ought to consider offering coursework that contain a segment of reflective writing as a major aspect of the formative assessment. All things considered, if this is actualized, undergraduates of such capacity like the one in this study would have been benefited from such assessment (Greene, 2014) and which they were allowed to form a broader perspective in relation to the module undertaken. This in turns will 
facilitate the development of reflective ability as a learned behavior (Gustafson \& Bennett, 1999).

By maintaining a learning log for the past fourteen weeks in this Entrepreneurship module, students can record and comment their every week entrepreneurship lesson in a profound manner. They can self-track their perspectives in their first class in this module and monitor their evolved entrepreneurship knowledge and perspectives as the lecture progress until the end of the semester. In the process, they immerse in self-discovery in the world of entrepreneurship and self-tracking personal growth and cognitive development. Reflective learning logs enable students to clearly identify their own thinking in entrepreneurship, the risks involved, the myths of becoming an entrepreneur, opportunity and execution intelligence - a method that promotes deep learning as depicted in the students' comments on the findings section in this study. Research has identified that reflection can help people to change. Although most of the students registering for this module are young undergraduate, and have limited experience to draw from to reflect upon certain issues (this is the findings from this study). But despite these barriers, reflective learning log make entrepreneurship learning congruent with the suggestion to teach entrepreneurship as a method rather than as a process. Reflective learning log provides students with a profound insight into their own world of academic and; hopefully in the future, their professional growth as reflection become a habit for our student.

\section{Acknowledgments}

This research would not have been possible without the funding from the Scholarship of Teaching and Learning (SoTL) Grant awarded by the Unit of Teaching and Learning Centre at the University Utara Malaysia (KOD SO 13396).

\section{References}

Angelo, T. A. (1991). Introduction and overview: From classroom assessment to classroom research. In T. A. Angelo, \& K. P. Cross (Eds.), Classroom research: Early lessons from success (pp. 7-15). San Francisco: Jossey-Bass. https://doi.org/10.1002/t1.37219914603

Chalk, P., \& Hardbattle, D. (2007). Does reflective writing in PDP improve science and engineering students learning? Investigations in University Teaching and Learning, 4(2), 33-41.

Cochran-Smith, M., \& Lytle, S. L. (1993). Inside outside: Teacher research and knowledge. New York: Teachers College Press.

Cowan, J. (1998). On becoming an innovative university teacher: Reflection in action. The Society for Research into Higher Education and Open University Press, UK.

Dewey, J. (1933). How we think? D.C. Heath and CO, Boston, MA.

Elliott, J. (1991). Action research for educational change. Philadelphia, PA: Open University Press.

Fiet, J. O. (2001). The pedagogical side of entrepreneurship theory. Journal of Business Venturing, 4(2), 101-117. https://doi.org/10.1016/S0883-9026(99)00042-7

Gray, D. E. (2004). Doing research in the real world. Thousand Oaks: Sage.

Greene, P. G. (2014). Four Approaches to Teaching Entrepreneurship as a Method. Babson College.

Gustafson, K., \& Bennett, W. (1999). Issues and difficulties in promoting learner reflection: Results from a three-year study.

Harvey, L., \& Knight, P. (1996). Transforming Higher Education. SRHE and Open University Press, Buckingham

Hatton, N., \& Smith, D. (1995). Reflection in teacher education - toward definition and Implementation. Teaching and Teacher Education, 11(1), 33-49. https://doi.org/10.1016/0742-051X(94)00012-U

Holland., L (2013). Student reflections on the value of a professionalism module. Journal of Information, Communication and Ethics in Society, 11(1), 19-30. https://doi.org/10.1108/14779961311304130

Katz, J. A. (2006). And another thing. White Paper, USASBE National Conference.

Katz, J. A. (2008). Fully mature but not fully legitimate: a different perspective on the state of entrepreneurship education. Journal of Small Business Management, 46(4), 550-566. https://doi.org/10.1111/j.1540-627X.2008.00256.x

Kneale, P. (1997). The rise of the 'strategic student': How can we adapt to cope? Facing Up to Radical Change in Universities and Colleges. 
Kuratko, D. F. (2004). Entrepreneurship education: emerging trends and challenges for the 21st century. Keynote Address at the US Association of Small Business and Entrepreneurship. Retrieved from https://www.usasbe.org/pdf/CWP-2003-kuratko.pdf

Kuratko, D. F. (2005). The emergence of entrepreneurship education: development, trends, and challenges. Entrepreneurship Theory \& Practice, 29(5), 577-597. https://doi.org/10.1111/j.1540-6520.2005.00099.x

Mair, C. (2011). Using technology for enhancing reflective writing, metacognition and learning. Journal of Further \& Higher Education, 36(2), 147-167. https://doi.org/10.1080/0309877X.2011.590583

Marshall, C., \& Rossman, G. B. (1999). Designing qualitative research (3rd ed.). Thousand Oaks: Sage.

Martinez, M. E. (2006). What is metacognition? Phi Delta Kappan, 87(9), 696-699. https://doi.org/10.1177/003172170608700916

Miller, C., Tomlinson, A., \& Jones, M. (1994). Researching Professional Education, University of Sussex.

Moon, J. (1999). Reflection in Learning and Professional Development: Theory and Practice. Kogan Page, London. https://doi.org/10.1038/21778

Schön, D. (1987). Educating the Reflective Practitioner. London: Jossey-Bass.

Shane, S. A. (2003). A General Theory of Entrepreneurship: The Individual-Opportunity Nexus. Edward Elgar Publishing, Cheltenham. https://doi.org/10.4337/9781781007990

Solomon, G. T. (2006). Are we teaching small business management to entrepreneurs and entrepreneurship to small business managers? White Paper, USASBE National Conference.

Stamper, C. (1996). Fostering reflective thinking through computer mediated journaling.

Strauss, A., \& Corbin, J. (1998). Basics of qualitative research: Grounded theory procedures and techniques (2nd ed.). Thousand Oaks: Sage.

Venkataraman, S. (1997). The distinctive domain of entrepreneurship research", Advances in Entrepreneurship. Firm Emergence and Growth, 3(1), 119-138.

Yinger, R. J., \& Clark, C. M. (1981). Reflective Journal Writing: Theory and Practice. Occasional Paper (50), Institute for Research on Teaching, Michigan State University.

\section{Appendix 1}

Records on the Total Subjects Taken and Total Subjects with Reflective Learning Log ( $=140$ students)

\begin{tabular}{|c|c|c|c|c|c|c|c|}
\hline Matric No. & $\begin{array}{c}\text { Total Subjects } \\
\text { Taken (Subject } \\
\text { with reflective } \\
\text { learning log) }\end{array}$ & Matric No. & $\begin{array}{c}\text { Total Subjects } \\
\text { Taken (Subject } \\
\text { with reflective } \\
\text { learning log) }\end{array}$ & Matric No. & $\begin{array}{c}\text { Total Subjects } \\
\text { Taken (Subject } \\
\text { with reflective } \\
\text { learning log) }\end{array}$ & Matric No. & $\begin{array}{c}\text { Total Subjects } \\
\text { Taken (Subject } \\
\text { with reflective } \\
\text { learning log) }\end{array}$ \\
\hline 219792 & $30(1)$ & 227437 & $17(1)$ & 225447 & $17(1)$ & 227810 & $20(1)$ \\
\hline 219868 & $25(2)$ & 227440 & $21(1)$ & 225513 & $18(1)$ & 227976 & $19(1)$ \\
\hline 220372 & $28(2)$ & 227576 & $21(2)$ & 225628 & $18(1)$ & 228031 & $20(1)$ \\
\hline 220488 & $30(2)$ & 227584 & $21(1)$ & 225707 & $17(1)$ & 228050 & $18(1)$ \\
\hline 220540 & $29(1)$ & 227875 & $19(1)$ & 225740 & $17(1)$ & 228068 & $18(1)$ \\
\hline 221390 & $29(1)$ & 228011 & $19(1)$ & 225837 & $19(1)$ & 228346 & $19(1)$ \\
\hline 221573 & $29(2)$ & 228018 & $19(2)$ & 225949 & $19(1)$ & 228348 & $19(1)$ \\
\hline 221577 & $29(1)$ & 228064 & $17(1)$ & 225955 & $18(1)$ & 228492 & $16(1)$ \\
\hline 221632 & $29(1)$ & 228382 & $19(1)$ & 225986 & $19(1)$ & 228504 & $17(1)$ \\
\hline 221812 & $28(1)$ & 228405 & $19(2)$ & 226036 & $18(1)$ & 229131 & $19(1)$ \\
\hline 221822 & $29(1)$ & 228416 & $18(1)$ & 226058 & $17(1)$ & 229135 & $18(1)$ \\
\hline 221862 & $29(1)$ & 228563 & $14(1)$ & 226100 & $18(1)$ & 216678 & $33(1)$ \\
\hline 222068 & $30(1)$ & 228592 & $15(1)$ & 226211 & $18(1)$ & 222146 & $30(1)$ \\
\hline 222071 & $29(1)$ & 229128 & $19(1)$ & 226309 & $18(1)$ & 223193 & $29(1)$ \\
\hline 222083 & $29(1)$ & 230227 & $12(1)$ & 226633 & $18(1)$ & 223206 & $31(1)$ \\
\hline 222302 & $33(1)$ & 230276 & $12(1)$ & 226689 & $18(1)$ & 223214 & $30(1)$ \\
\hline 222342 & $28(1)$ & 219701 & $30(1)$ & 226857 & $18(1)$ & 223244 & $29(1)$ \\
\hline 224135 & $23(1)$ & 220781 & $30(1)$ & 227145 & $18(1)$ & 223305 & $29(1)$ \\
\hline
\end{tabular}




\begin{tabular}{|l|l|l|l|l|l|l|l|}
\hline 225622 & $18(1)$ & 220807 & $29(1)$ & 227160 & $18(1)$ & 225727 & $29(1)$ \\
\hline 225976 & $18(1)$ & 221298 & $28(1)$ & 227167 & $17(1)$ & 225776 & $18(1)$ \\
\hline 226101 & $21(1)$ & 221318 & $28(1)$ & 227272 & $17(1)$ & 225781 & $18(1)$ \\
\hline 226168 & $19(1)$ & 221447 & $30(1)$ & 227315 & $19(1)$ & 226106 & $18(1)$ \\
\hline 226245 & $18(1)$ & 222041 & $29(1)$ & 227492 & $19(1)$ & 226176 & $18(1)$ \\
\hline 226281 & $18(1)$ & 222093 & $29(1)$ & 227599 & $17(1)$ & 226184 & $18(1)$ \\
\hline 226296 & $18(1)$ & 223304 & $18(1)$ & 227606 & $18(1)$ & 226297 & $18(1)$ \\
\hline 226566 & $18(1)$ & 225280 & $18(1)$ & 227649 & $18(1)$ & 226321 & $18(1)$ \\
\hline 226958 & $17(1)$ & 225329 & $17(1)$ & 227663 & $18(1)$ & 226323 & $17(1)$ \\
\hline 227379 & $18(1)$ & 225378 & $17(1)$ & 227685 & $18(1)$ & 226328 & $20(1)$ \\
\hline 226426 & $18(1)$ & 226591 & $18(1)$ & 226704 & $18(1)$ & 227525 & $18(1)$ \\
\hline 226430 & $18(1)$ & 226608 & $18(1)$ & 226718 & $18(1)$ & 227569 & $19(1)$ \\
\hline 226438 & $18(1)$ & 226616 & $18(1)$ & 226764 & $18(1)$ & 227868 & $18(1)$ \\
\hline 226456 & $17(1)$ & 226688 & $18(1)$ & 227075 & $18(1)$ & 227901 & $18(1)$ \\
\hline 227919 & $19(1)$ & 228301 & $18(1)$ & 227390 & $18(1)$ & 229129 & $18(1)$ \\
\hline 227982 & $18(1)$ & 228303 & $18(1)$ & 227445 & $17(1)$ & 230183 & $12(1)$ \\
\hline 227983 & $18(1)$ & 228340 & $18(1)$ & 228273 & $19(1)$ & 228350 & $18(1)$ \\
\hline
\end{tabular}

\section{Appendix 2}

\section{Mark Sheets for Reflective Learning $\log (10 \%)(\mathrm{N}=136)$}

\begin{tabular}{|c|c|c|c|c|c|c|c|c|c|}
\hline $\begin{array}{c}\text { Matric } \\
\text { No. }\end{array}$ & $\begin{array}{l}\text { Reflective } \\
\text { Learning } \\
\text { Log }(10 \%)\end{array}$ & $\begin{array}{c}\text { Matric } \\
\text { No. }\end{array}$ & $\begin{array}{c}\text { Reflective } \\
\text { Learning Log } \\
(10 \%)\end{array}$ & $\begin{array}{c}\text { Matric } \\
\text { No. }\end{array}$ & $\begin{array}{c}\text { Reflective } \\
\text { Learning Log } \\
(10 \%)\end{array}$ & $\begin{array}{c}\text { Matric } \\
\text { No. }\end{array}$ & $\begin{array}{c}\text { Reflective } \\
\text { Learning Log } \\
(10 \%)\end{array}$ & $\begin{array}{c}\text { Matric } \\
\text { No. }\end{array}$ & $\begin{array}{c}\text { Reflective } \\
\text { Learning Log } \\
\quad(10 \%)\end{array}$ \\
\hline 219792 & 6 & 227437 & 5 & 225447 & 5 & 227810 & 6 & 226426 & 5 \\
\hline 219868 & 6 & 227440 & 5 & 225513 & 5 & 227976 & 6 & 226430 & 5 \\
\hline 220372 & 6 & 227576 & 8 & 225628 & 5 & 228031 & 6 & 226438 & 5 \\
\hline 220488 & 6 & 227584 & 6 & 225707 & 5 & 228050 & 5 & 226456 & 5 \\
\hline 220540 & 5 & 227875 & 5 & 225740 & 5 & 228068 & 5 & 226591 & 5 \\
\hline 221390 & - & 228011 & 6 & 225837 & 4 & 228346 & 4 & 226608 & 6 \\
\hline 221573 & 6 & 228018 & 5 & 225949 & 5 & 228348 & 4 & 226616 & 5 \\
\hline 221577 & - & 228064 & 5 & 225955 & 5 & 228492 & 5 & 226688 & 7 \\
\hline 221632 & - & 228382 & 5 & 225986 & 4 & 228504 & 5 & 226704 & 5 \\
\hline 221812 & 6 & 228405 & 5 & 226036 & 4 & 229131 & 5 & 226718 & 5 \\
\hline 221822 & 6 & 228416 & 7 & 226058 & 5 & 229135 & 6 & 226764 & - \\
\hline 221862 & 7 & 228563 & 5 & 226100 & 5 & 216678 & 1 & 227075 & 5 \\
\hline 222068 & 6 & 228592 & 5 & 226211 & 6 & 222146 & 5 & 227390 & 5 \\
\hline 222071 & 5 & 229128 & 6 & 226309 & 5 & 223193 & 7 & 227445 & 5 \\
\hline 222083 & 6 & 230227 & 5 & 226633 & 6 & 223206 & 5 & 227525 & 6 \\
\hline 222302 & 5 & 230276 & 8 & 226689 & 4 & 223214 & 5 & 227569 & 6 \\
\hline 222342 & 6 & 219701 & 5 & 226857 & 6 & 223244 & 7 & 227868 & 5 \\
\hline 224135 & 5 & 220781 & 6 & 227145 & 8 & 223305 & 6 & 227901 & 5 \\
\hline 225622 & 3 & 220807 & 5 & 227160 & 4 & 225727 & 7 & 227919 & 6 \\
\hline 225976 & 5 & 221298 & 5 & 227167 & 5 & 225776 & 6 & 227982 & 5 \\
\hline 226101 & 5 & 221318 & 7 & 227272 & 8 & 225781 & 5 & 227983 & 6 \\
\hline 226168 & 8 & 221447 & 6 & 227315 & 4 & 226106 & 7 & 228273 & 7 \\
\hline 226245 & 7 & 222041 & 5 & 227492 & 5 & 226176 & 7 & 228301 & 6 \\
\hline 226281 & 7 & 222093 & 6 & 227599 & 7 & 226184 & 5 & 228303 & 9 \\
\hline 226296 & 6 & 223304 & 6 & 227606 & 6 & 226297 & 5 & 228340 & 9 \\
\hline 226566 & 6 & 225280 & 5 & 227649 & 5 & 226321 & 7 & 228350 & 5 \\
\hline 226958 & 6 & 225329 & 7 & 227663 & 5 & 226323 & 5 & 229129 & 5 \\
\hline 227379 & 8 & 225378 & 8 & 227685 & 5 & 226328 & 7 & 230183 & 7 \\
\hline
\end{tabular}




\section{Copyrights}

Copyright for this article is retained by the author(s), with first publication rights granted to the journal.

This is an open-access article distributed under the terms and conditions of the Creative Commons Attribution license (http://creativecommons.org/licenses/by/4.0/). 